\title{
ФЕНОМЕН МОВИ В РОЗУМІННI І. ФРАНКА (НА МАТЕРІАЛІ ПОЛЬСЬКОМОВНОЇ СТАТТІ В ЧАСОПИСІ „ZIARNO”)
}

\author{
ІРИНА КАПАНАЙКО \\ Дрогобицький державний педагогічний університет імені Івана Франка, \\ Дрогобич - Україна \\ FENOMEN JĘZYKA W ROZUMIENIU IWANA FRANKI \\ (NA MATERIALE POLSKOJĘZYCZNEGO ARTYKUŁU \\ W CZASOPIŚMIE „ZIARNO”) \\ IRYNA KAPANAJKO \\ Państwowy Uniwersytet Pedagogiczny imienia Iwana Franki w Drohobyczu, \\ Drohobycz - Ukraina
}

STRESZCZENIE. W artykule zaprezentowane zostały rozważania I. Franki o języku ukraińskim, zamieszczone na łamach czasopism polskich. Na materiale polskich artykułów prasowych, przetłumaczonych na język ukraiński, wyraziście uwypuklone zostało stanowisko pisarza odnośnie funkcjonowania języka. Podkreślono również perspektywiczność postulatów i twierdzeń I. Franki w odniesieniu do współczesnego językoznawstwa.

\section{THE PHENOMENON OF LANGUAGE IN I. FRANKO'S UNDERSTANDING (ON THE MATERIAL OF THE POLISH LANGUAGE ARTICLE IN THE JOURNAL “ZIARNO”)}

\section{IRYNA KAPANAIKO}

Drohobych Ivan Franko State Pedagogical University, Drohobych — Ukraine

ABSTRACT. The article focuses on the analysis of I. Franko's reasonings concerning the language on the columns of Polish periodicals. Clear position of the publicist as for the language functioning has been illustrated basing on the materials of newspaper articles and notes, translated into Ukrainian. The writer's prospects of the development of modern linguistics have been determined.

I

ван Франко ставив високі вимоги до тих науковців, які розмірковували про мову. На його думку, ця особистість зобов'язана знати „часові й місцеві переміни” мови, „еволюцію ії звуків, флексії та синтакси"1. Українська мова, як відомо, поширена на великому просторі й розділена кордонами чужих держав, де всюди має свої особливості розвитку; отже, треба знати ії у всіх виміpax, знати ,„ї історичні переходи та їх сліди в сучасній мові”. Однак це ще не все. На думку I. Франка, треба знати не лише розвій самої мови, а й розвій правопису і не лише українського, але й інших мов²; слід керуватися настановою, що „живий язик можна і треба студіювати як живу рослину, але не можна

${ }^{1}$ І. Франко, , Украӥна” науковий та літературно-публіцистичний щомісячний журнал, [в:] його ж, Зібрання творів, в 50 тт., Київ 1985, т. 37, с. 244.

2 Там само, с. $244,246$. 
і не слід засушувати і заковувати в мертві правила й формули"з. Лінгвіст повинен мати виважену позицію щодо взаємин національного та інтернаціонального, насамперед тоді, коли йдеться про наукову термінологію, мусить враховувати особливості розвитку жанрово-стильових різновидів національної мови тощо. Зразком реалізації таких вимог є підхід І. Франка до мовних явищ, їх глибокий аналіз, його мовна практика, що має потужну силу4

Важливо, що, працюючи в польських видавництвах і створюючи публіцистичні тексти польською мовою, І. Франко усвідомив, що основні аргументи на підтвердження самостійності української мови в другій половині XIX ст. стосувалися радше мовознавчих, ніж історичних чинників, передусім поширеною на той час була думка, що малоруська мова відзначена унікальністю мовної форми, а думка про те, що малоруська мова була утворена від змішування 3 польською, заперечувалася тим фактом, що в ній не було більшості відповідних звукових характеристик, які мали місце в мові польській. Насправді в українську мову перейшло багато як польських, так і російських слів, але акцент ставився на необхідності вирізняти ті слова, що, перейшовши з тієї чи тієї мови, склалися в українській на свій зразок від безпосередньо російських чи польських ${ }^{5}$. Подальший розвиток української мови дедалі більше свідчив про іiі самостійність. Основною особливістю висхідного положення української мови було те, що весь процес іiі розвитку був спрямований на спрощення вимови, а це не спостерігалося ані в польській мові, ані в російській. Загалом питання статусу української мови наприкінці XIX сторіччя вирішилось: науково доведений факт самостійного існування мови зводив нанівець все ще існуючі спроби заперечити іiі „окремешність”.

Мовний феномен I. Франка, енергетика його писемного та живого слова очевидні, але тлумачення такого явища потребує всебічного підходу, особливо в час, коли до письменника прийшло усвідомлення, що його „слух, отворений на голоси духів”, коли „світ духів” для нього виявився природним ${ }^{6}$. Психологи такі моменти пояснюють унікальністю. Цим сказано власне те, що готових схем, аналогів тут немає. У такій ситуації залишається фіксувати вияви небуденного явища, уникати абсолютизації та категоричності у висновках.

Цілісний та органічний огляд франкових тверджень доводить його своєрідне трактування мови, що не залежало від ситуації й місця написання відповідних праць. Життєвий принцип — „говорити народу, всю правду” — відображений і на сторінках польської періодики. Хоча хронологічно публікації письменника в цій пресі й створені швидше, ніж україномовні статті, проте сила слова завжди вражає, а мовні погляди будують безмежний спектр франкових лінгвістичних положень.

Ще на світанку своєї праці в польській періодиці 1883 р. в газеті „Ziarno” I. Франко опублікував статтю $O$ czem i jak należy pisać dla ludu. Тут він висловлює концептуальні думки стосовно мови та іiі розвитку, що становлять підгрунтя його мовних принципів. Над „питаннями язиковими”, як сам I. Франко про це писав, йому доводилося багато розмірковувати ${ }^{7}$.

Франкознавці зазначають, що природне чуття живої, чистої народної мови, що змалечку проявилося в письменника, сильно розвинулося: дар „ословеснювати" все, що торкалося його вуха, на чому відпочивало зацікавлене око, гене-

${ }^{3}$ Там само, с. 206.

${ }^{4}$ О. С ербенська, Мовний світ Івана Франка, Львів 2006, с. 30.

${ }^{5}$ О некоторых фонетических и грамматических особенностях южнорусского (малорусского) языка, не сходных с великорусским и польским, [в:] „Правда”, 1868, № 4, с. 3.

${ }^{6}$ О. Сербенська, Зазнач. праия, с. 123.

${ }^{7}$ I. Франко, “Украӥна” науковий та літературно-публічистичний щомісячний журнал, [в:] його ж, Зібрання творів, в 50 тт., Київ 1985, т. 37, с. 205. 
тична здатність фіксувати в пам'яті спосіб мовлення рідних, знайомих, подивляти гарну бесіду, а ще праця впродовж усього свідомого життя над збиранням лексичного та фразеологічного матеріалу, багатьох інших творів усної словесності, - усе це, зміцнене енциклопедичними знаннями в галузі гуманітарних і природничих наук, підсилене грунтовною лінгвістичною освітою, практичним знанням багатьох мов та історією їхнього розвою, дало I. Франку міцну основу для витворення цілісної концепції слова, розуміння особливостей розвитку та функціонування рідної мови, яку він уважав атрибутом людської сутності й складовою іï етики

Отже, цілком логічною й справді фундаментальною у польськомовній статті письменника $є$ теза, „що повинно служити народу, передусім має бути для нього зрозумілим, повинно користовуватися його власною мовою"я. Далі письменник $з$ попередньої тези будує наступну, й так продовжує, приводячи читача до осмислення важливих мовних категорій. Використовуючи такий своєрідний метод, I. Франко не просто аналізує поставлені питання, а намагається побачити їх глибоку суть у міжмовній культурній взаємодії, тому, розвиваючи вже народжену засаду, пише про необхідність використання „часто навіть його (народу - I. К.) діалект або жаргон, — звідси й пішла в наш вік ця незмірна децентралізація мовних форм, в які зодягалася думка і наука, - звідси й поява такої кількості нової літератури в мовах малих народів, знайомих і цілком забутих, звідси вивчення всіх дрібних відтінків та місцевих різновидів мови та етнографії якоїсь нації.... Малі мови та наріччя виходять на зовні з довгого забуття, домагаючись і для себе рівноправності серед більш вироблених державних мов - на духовному рівні це те саме явище, яке бачимо на суспільному та економічному"10. У статті про М. Старицького I. Франко наголошував, що мовознавець повинен перейнятися ,любов’ю до розвою живого слова, здібний заглядати в глибину того розвою, в його пружини й переходи"11. „До таких прикмет, що відповідають складові душі... належить і мова"12. Як бачимо, заглядав письменник далеко за обрій людського існування. Для мовознавства подібні міркування — це цілком новий, непересічний погляд.

I. Франко-енциклопедист розглядав мову в тісному зв'язку з мисленням, духовним світом людини, вважав мову динамічною дійовою силою, здатною стимулювати процес пізнання дійсності, бути могутнім засобом іiі інтерпретаціiі. „Виражаючи якісь думки в певній мові, ще не обов’язково будемо зрозумілими для народу, який розмовляє цією мовою. Потреба вміти пристосуватися до розумінь, уявлень і способу мислення цього народу, - потреба сформувати загальнолюдські думки в якусь спеціальну, доступну та своєрідну форму для цього народу, так як музикант може змінити певну арію, не змінюючи їі системи, а проводячи з однієї тонації в іншу, споріднену"13. Таке трактування мови як самої сутності людини, явища найбільш людського, яке пов'язане 3 „духом”, „душею народу”, духовністю, 3 тими духовними пластами, що накладають на людину відповідні устої в сім’і, система виховання, середовище, соціальноекономічний устрій — це ще одна мовна засада великого Каменяра. Зв'язок

${ }^{8}$ O. Сербенська, Зазнач. праия, с. 28.

${ }^{9}$ I. Franko, O czem i jak należy pisać dla ludu, [w:] „Ziarno”, 1883, № 5, 27.0I, s. 49.

${ }^{10}$ Там само, с. 50.

${ }^{11}$ I. Франко, Михайло П[етрович] Старицький, [в:] його ж, Зібрання творів, в 50 тт., Київ 1985 , т. 33, c. 231.

${ }^{12}$ Там само, c. 276.

${ }^{13}$ I. Franko, O czem i jak należy pisać dla ludu.., s. 50. 
народу та його мови згодом письменник досліджував практично все своє життя. Однак зародження цих ідей спостерігаємо на шпальтах не вельми значної в його публіцистичній діяльності газети „Ziarno”. Ці перли-думки I. Франко пізніше посіє й у своїх наукових працях. Зрештою, розум генія і провидця прийшов до визнання „вродженої прикмети мови”, тобто до усвідомлення того, що існує певний мовний генотип особистості ${ }^{14}$, що $є$ серйозною науковою проблемою.

А про те, що сьогодні вважають досягненням науки - йдеться про перенесення акценту зі статичності на динаміку, тобто на людину, яка й породжує, й сприймає стильові різновиди мови ${ }^{15},-$ I. Франко говорив ще понад сто років тому, в чому переконуємося, розглядаючи лише частковості цієї складної проблеми.

Принципи боротьби за утвердження прав української мови як окремої одиниці в світі інших мов стають зрозумілими з огляду на проаналізовані твердження I. Франка в часописі „Ziarno”. Тут письменник зосередив свою увагу не лише на явищі загального мовного розвитку, а, швидше за все, він повільно підходив до пояснення феномену української мови. Є підстави вважати публікацію O czem i jak należy pisać dla ludu важливою ланкою в розкритті майбутніх цілей письменника.

Підкреслимо, що I. Франко як великий український державник і соборник постійно дбав про розвиток української мови, науки про неї та іiї місця в школі й суспільно-громадському та політичному житті України (не лише Галичини). Він палко й відповідально підтримував усі починання в цій царині як учений, письменник і відданий українець. Діяльність Каменяра в польській пресі - це зародження демократичної думки поза межами України, тому так важливо було, аби ця думка сприяла розвитку української культури та мови зокрема. Зрештою, в той час кожна суспільна подія безпосередньо чи віддалено стосувалася й мовного питання, а без вирішення цієї проблеми гальмувалися перспективи української науки. Вивчаючи та аналізуючи публіцистичний матеріал I. Франка, надрукований в польській періодиці, простежуємо не просто пояснення мовних проблем чи огляд подій щодо становлення української мови: на шпальтах іноземної преси письменник намагається дослідити феномен мови та як провідник нації визначити значимість української мови. Завдяки журналістській майстерності йому вдається розробити своєрідний план подолання україномовної занедбаності та відродження культурно-мовного процесу через пробудження зацікавленості до всього національного — як інтелігенції, науковців, так і простого народу.

Користуючись підтримкою польської демократичної преси, І. Франко висловлює низку поглядів, що, як видається, розкривають сутність його лінгвістичних ідей. Каменяр вірив, що суспільний розвиток може відбуватися лише за умови повноцінного функціонування мови, тобто все, що повинно служити народу, повинно бути для нього зрозумілим і доступним мовою, яку сприймає серце, - батьківською. Якщо виховання, навчання, праця та й, зрештою, наука співіснують із мовними процесами, то україномовний прогрес неминучий, тому в одній із своїх статей в газеті „Przegląd społeczny” I. Франко зазначає: „Не пишучи зовсім рідною мовою, не матимемо наукової літератури в українській мові"16. Ці очевидні факти мав сміливість критикувати письменник в іноземному осередку, викриваючи складне культурне становище земляків, що не

${ }^{14}$ О. Сербенська, Зазнач. праия, Львів 2006, с. 87.

${ }^{15}$ Украйнська мова. Енциклопедія, редкол. В. М. Русанівський, О. О. Тараненко та ін., Київ 2000 , c. 603.

${ }^{16}$ I. Frank o, Przeglad spraw krajowych za miesiac styczeń 1887, [w:] „Przegląd społeczny”, 1887, № 2 , t. 3, s. 180 . 
менш залежало й від ставлення самих українців до проблеми. Можливо, така ситуація склалася через страх зробити рішучий крок до утвердження своїх національних прав або народну пасивність, i, що гірше, незнання, яке підсилювала влада. I. Франко знав українців, їх характер, тому мав право писати правду про свій народ. Отже, зрозуміло одне: не тільки виключно іноземні кривдники оточували українське суспільство, боротьбу потрібно починати із „пробудження" національної свідомості; ,зламання духу” письменник уважав істинною згубою для розвитку української мови.

I. Франко звертав увагу на говори, наріччя, що для нього були перлами в мовній скарбниці. Звісно ж, про це писав учений у своїх працях, але підгрунтя своїх поглядів він заклав на шпальтах польської періодики, де ще 1883 р. зазначав: „Аби для народу було все зрозуміле, повинен (письменник - I. К.) використовувати його власну мову, часто навіть діалекти або жаргони"17. Цей ранній період творчості пожвавив наступні напрацювання. Діалектологічні погляди I. Франка викладено в статті Літературна мова і діалекти (1907 р.). Він чітко розрізняв і послідовно вивчав територіальні й соціальні діалекти, визначив їх особливості, вказав на характер взаємодії літературної мови й діалектів, дав класифікацію західноукраїнських говорів, що майже не відрізняється від прийнятої сучасною діалектологією. Оскільки ця тема вже висвітлена у франкознавстві, то не бачимо доцільності їі деталізувати, більше того, об'єктом наших досліджень є польськомовні публікації письменника. Однак не можемо оминути статтю Говоримо про вовка, скажімо $i$ за вовка („Зоря”, 1891, ч.18), 3 якою I. Франко вступив у полеміку з автором „Галицьких віршів” (Правда, 1891, вип. 8-10) Б. Грінченком, що вкотре продемонструвало велич ідей Каменяра та показало силу його думки (у газеті „Ziarno” маємо лише штрихи поглядів I. Франка, що, як видається, знайшли своє призначення у феноменальній публікації Говоримо про вовка, скажімо $і$ за вовка).

Стаття I. Франка є фундаментальним викладом його глибинних міркувань щодо української мови загалом і літературної мови зокрема та місця „галицизмів”, діалектів у ній. Письменник відзначає, що полеміка навколо мови „галицьких віршів" ведеться давно (останній раз в Австро-руських споминах М. Драгоманова було порушено це питання). Виходячи з глибинного розуміння суті справи, I. Франко пише: „Мені бажалось би своїми увагами докинути цеглинку до взаємного порозуміння між українцями й галичанами на полі язиковім i таким способом причинитися до полагодження одного дуже важного питання - будущої єдності, і одноцільності нашої літературної мови, будущої, повторяю, бо тепер ми ще іiі не маємо і задля звісних, дуже важних причин, мати не можемо" (жирний шрифт авторський - I. К.) ${ }^{18}$. Учений наголошує, що „....народ (галичани - I. К.) з його мовою, звичаями і творчістю” ніколи не сходив зі спільної української основи, хоча й витворив багато власних відтінків. „Ані знівечити, ані замазати тих відтінків не можна, та й чи треба? Адже ж се не жадне крадене добро, а здобутки дійової праці, котрі чомусь же народились і повинні вийти на пожиток цілісності"19.

Для загальної картини розуміння I. Франком таємниці мови ще пригадаймо його трактат Із секретів поетичної творчості, де, досліджуючи мовні процеси, Каменяр дійшов до аналізу ментальності народу, звичайно, не викорис-

${ }^{17}$ I. Franko, O czem i jak należy pisać dla ludu.., s. 50.

18 І. Франко, Говоримо на вовка - скажімо $і$ за вовка, [в:] його ж, Зібрання творів, в 50 тт., Київ 1985, т. 28, с. 171.

${ }^{19}$ Там само. 
товуючи цей термін у той час, але окреслив його значення, вказуючи шлях до розуміння такого поняття: „Потреба вміти пристосуватися до розумінь, уявлень і способу мислення цього народу, - потреба сформувати загальнолюдські думки в якусь спеціальну, доступну та своєрідну форму для цього народу, так як музикант грає певну арію, не змінюючи ії системи, а проводячи з однієї тонації в іншу, споріднену”. Не достатньо лише володіти мовою, важливо збагнути ії дух. „Тілько вглубляючи ся в духа мови (жирний шрифт авторський I. К.), ми можемо вияснити собі процес естетичної уяви"20. Так пише I. Франко у трактаті Із секретів поетичної творчості (1913р.), вже висловлюючи там свої погляди та ідеї.

Як розумів I. Франко поняття „дух мови”? Це можна пояснити лише тим, що мова (те й доводив у своїх працях дослідник) - це “жива струна" народу, що вбирає усі його частинки. Лише осягнувши мовний світ нації, можна оцінити проблеми та перспективи ії розвитку. Отже, великий мислитель своїм ученням випередив час і дав поштовх для подальшого розуміння цього феномену прийдешніми поколіннями. Вчений завжди намагався нормувати процес становлення української мови; розкривати сутність мовних явищ, в яких слово - первинна ланка.

Феноменальність I. Франка - у мозаїчному сприйнятті світу, де мова — це не просто довершена форма цих мозаїчних лабіринтів, - вона дорога, якою йде нація. Дослідження мови в діахронії - це шлях суспільства та особистості до власного першопочатку та регресу. Письменник „часує” українську мову відповідно до суспільно-ідейної епохи, а точніше, його візія кожної суспільної епохи і $є$ мовою. Природно, як пише I. Фаріон, що термінологічний матеріал, використаний мислителем під час аналізу мовних артефактів, відображає не лише тодішній рівень лінгвістичної термінології, але оприявнює глибинні когнітивно-суспільні та ідеологічні процеси. Стрижневими мовними термінами є метатерміни „мова” — „язик” та їхні атрибутивні чи етноатрибутивні окреслення. Віднайдення відповідного терміна - це словесно-матеріальне завершення когнітивної структури й водночас початок наукового термінування світу, через те використання їх у франковому дискурсі має подвійне значення: розкриває сприйняття письменником цих термінів і відображає їхню еволюцію в загальнолінгвістичних українських процесах ${ }^{21}$.

Віддаючи належне поглядам I. Франка, в яких відображена орієнтація письменника на загальнолюдське, мусимо визнати, що все в нього пронизане розумінням сутності людини, в усьому простежуємо велику увагу до мови. Навіть у коротких текстах анотаційного характеру він виявляв особливості мовного процесу, оцінював факти, що стосуються розвитку української мови. Втім, заслуга Каменяра беззаперечна. Польська трибуна виявилася для нього діяльним полем для утвердження патріотично-національних лінгвістичних положень.

Ця стаття задекларувала важливу проблему. Репрезентовано спробу подати авторське розуміння франкової інтерпретації феномену мови. Каменяр показав перспективи унормування української мови, сформулював основні засади іiі розвитку, провів паралелі між статусом української мови й іншими мовами світу на європейському рівні. Однак детальніший огляд його тверджень, репрезентованих у польських часописах, — це справа майбутнього.

${ }^{20}$ І. Франко, Із секретів поетичної творчості, [в:] його ж, Зібрання творів, в 50 тт., Київ 1985 , т. 37 , с. 138 .

${ }^{21}$ I. Фаріон, Франкова візія історії української мови (XI - XVIII cm.), [в:] “Дивослово”, 2006, № 10 , c. 39 . 